\title{
Chronostratigraphy of the sedimentary record of Limnopolar Lake, Byers Peninsula, Livingston Island, Antarctica
}

\author{
MANUEL TORO ${ }^{1}$, IGNACIO GRANADOS ${ }^{2}$, SERGI PLA ${ }^{3}$, SANTIAGO GIRALT ${ }^{4}$, DERMOT ANTONIADES ${ }^{5}$, \\ LUIS GALÁN ${ }^{6}$, ANTONIO MARTÍNEZ CORTIZAS ${ }^{7}$, HYOUN SOO LIM ${ }^{8}$ and PETER G. APPLEBY ${ }^{9}$ \\ ${ }^{1}$ Centro de Estudios Hidrográficos (CEDEX), Paseo Bajo Virgen del Puerto, 3, 28005 Madrid, Spain \\ ${ }^{2}$ Parque Natural de Peñalara, Centro de Investigación y Gestión Puente del Perdón, Ctr. M-604, Km 27.6, 28740 Rascafría, Spain \\ ${ }^{3}$ CSIC-CEAB, Biogeodynamics and Biodiversity Group, C/ Carrer Acces Cala St. Francesc 14, 17300 Blanes, Spain \\ ${ }^{4}$ Institute of Earth Sciences, Jaume Almera (CSIC), Lluís Solé i Sabarís s/n, 08028 Barcelona, Spain \\ ${ }^{5}$ Centre d'études Nordiques, Pavillon Abitibi-Price, Université Laval, Québec, Québec G1V 0A6, Canada \\ ${ }^{6}$ Instituto Geológico y Minero de España - IGME, Ríos Rosas 23, 28003 Madrid, Spain \\ ${ }^{7}$ Departamento de Edafoloxía e Química Agrícola, Facultade de Bioloxía - Rúa Lope Gómez de Marzoa, s/n, Campus Vida, \\ 15782 Santiago de Compostela, Spain \\ ${ }^{8}$ Department of Geological Sciences, Pusan National University, Pusan 609-735, Korea \\ ${ }^{9}$ Department of Mathematical Sciences, University of Liverpool, Liverpool L69 3BX, UK \\ manuel.toro@cedex.es
}

\begin{abstract}
The chronostratigraphy of the sedimentary record of Limnopolar Lake, located on Byers Peninsula (Livingston Island, South Shetland Islands, Maritime Antarctica), is described based on radionuclides and radiocarbon age dating. The oldest moss macrofossil age was $6700 \pm 50 \mathrm{yr}$ BP ( $7510 \pm 80 \mathrm{cal} \mathrm{yr} \mathrm{BP)} \mathrm{from} \mathrm{which} \mathrm{the} \mathrm{age/depth} \mathrm{model} \mathrm{estimates} \mathrm{a} \mathrm{basal} \mathrm{age} \mathrm{for} \mathrm{the} \mathrm{sedimentary} \mathrm{record} \mathrm{of}$ c. 8300 cal yr BP, suggesting an earlier deglaciation of Byers Peninsula than reported in previous studies. Lithological units and other stratigraphic zones are described throughout the sediment core, showing different mineralogical composition and a fine alternation of clays and silty clays and moss layers of Drepanocladus longifolius. Based on magnetic susceptibility analyses, a number of probable primary and reworked tephra layers were identified, seven of them confirmed by SEM observations, and most of them in agreement with the regional tephrachronology stratigraphy for the north-west Antarctic Peninsula. Sedimentation rates showed no significant changes during the last 5000 years with the exception of an abrupt event that took place around $5400 \mathrm{cal} \mathrm{yr} \mathrm{BP,} \mathrm{which} \mathrm{implied} \mathrm{the} \mathrm{sedimentation} \mathrm{of} c .30 \mathrm{~cm}$ of clays in a very short time, probably related to a period of glacial re-advance that caused abrupt changes in geomorphological processes in the catchment.
\end{abstract}

Received 5 April 2012, accepted 3 July 2012

Key words: ${ }^{137} \mathrm{Cs}$ dating, deglaciation, Drepanocladus longifolius, ${ }^{210} \mathrm{~Pb}$ dating, radiocarbon dating, tephrachronology

\section{Introduction}

In a global framework of climate change, palaeoclimatic studies play an important role in improving understanding of past climate variability on longer timescales than those provided by recent monitoring networks. The importance of these studies is greater in high latitudes, where recent climate changes have been more extreme than in the rest of the world, with the terrestrial cryosphere and hydrology being increasingly affected (Anisimov et al. 2007). In the Southern Hemisphere, the mean annual air temperature of the Antarctic Peninsula region warmed by around $2.8^{\circ} \mathrm{C}$ during the last 50 years, which represents one of the highest increases anywhere in the world (Vaughan et al. 2003, Turner et al. 2005). This warming has profound implications for lakes. Palaeoclimatic studies in the Antarctic Peninsula region (Ingólfsson 2004) have shown marked climatic fluctuations during the postglacial period, which probably caused glacial advances and retreats and hence environmental changes in aquatic ecosystems. For example, the temperatures and annual ice-free periods of lakes on Signy Island have increased remarkably over the last 50 years (Quayle et al. 2002). The South Shetland Islands, located at the northern tip of the Antarctic Peninsula, is one of the Antarctic regions with the greatest number of inland freshwater bodies, and constitutes one of the best Antarctic areas for reconstruction of past environmental changes. On Byers Peninsula, at the west end of Livingston Island, the high number of lakes makes this area highly suitable for palaeolimnological studies. Furthermore, nearby Deception Island ( $30 \mathrm{~km}$ away) has the most active volcano in the Antarctic Peninsula region, which has produced distinctive tephra layers in the sedimentary record of Byers Peninsula lakes (Björck et al. 1991a, Björck \& Zale 1996, Hodgson et al. 1998). Tephra layers are useful for refining sediment chronostratigraphies, providing independent constraints and helping to identify 


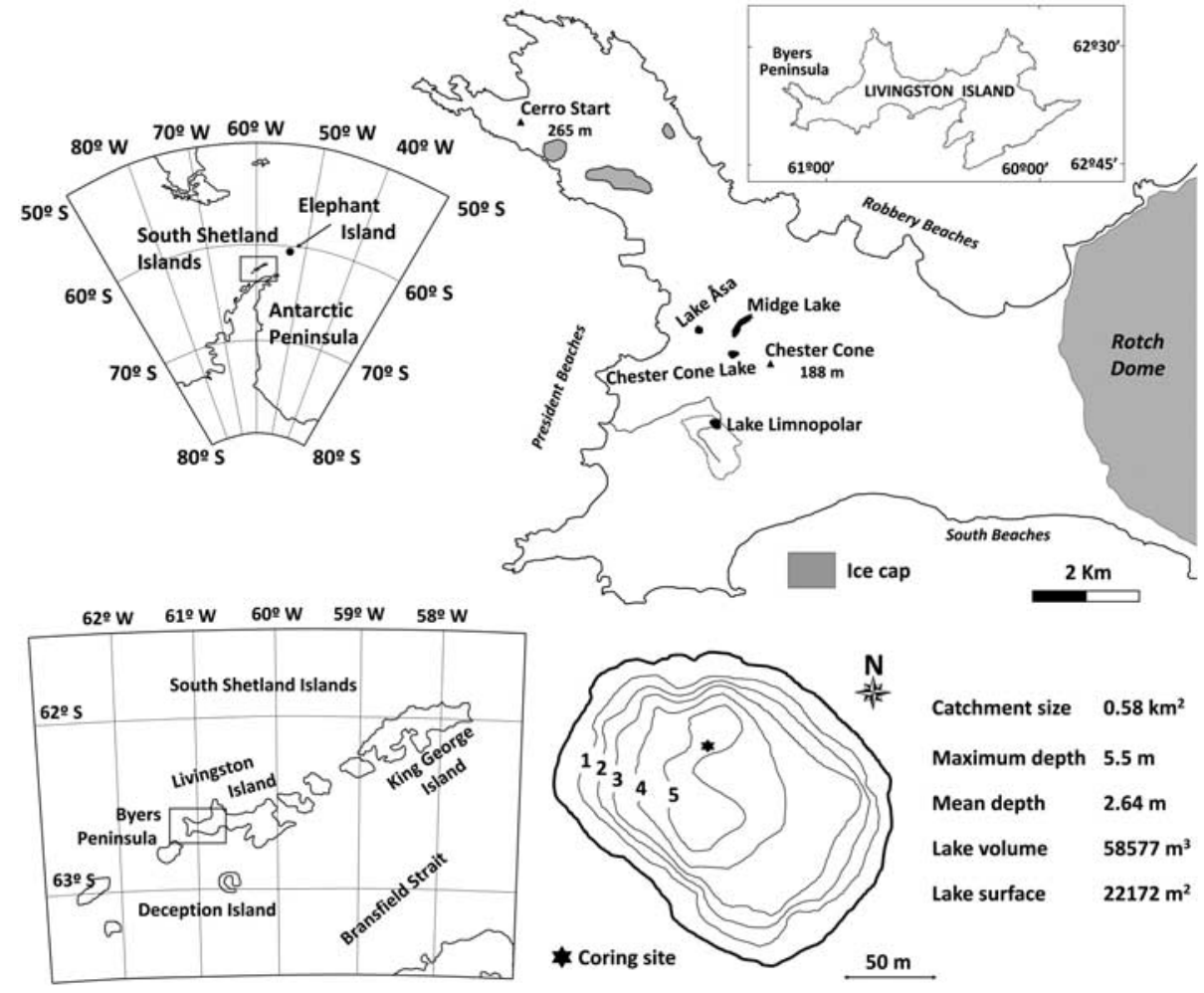

Fig. 1. Geographical location of Limnopolar Lake on Livingston Island (South Shetland Islands), the lake and its watershed morphometric characteristics, and a bathymetric map with the location of sediment coring. Main referenced sites in the text from other studies are located in the figure. any inconsistencies in the ${ }^{14} \mathrm{C}$ dating which have sometimes been encountered in the South Shetland Islands area (Björck et al. 1991b, Hodgson et al. 2004, Wolfe et al. 2004). Inventories of tephra horizons and their geochemical characterization have been produced for this area (Baker et al. 1975, Björck et al. 1991a, Björck \& Zale 1996) with eight different tephra horizons detected in Livingston Island sedimentary records (AP1, AP2, AP3, AP5, AP10, AP11, AP12 and AP14), the oldest one (AP14) dating to c. $4700{ }^{14} \mathrm{C}$ yr BP (Björck et al. 1991a).

In Byers Peninsula the sedimentary records of three lakes have been studied recently: Midge Lake (Björck et al. 1991c, 1991b, Hodgson et al. 1998), Chester Cone Lake (Björck et al. 1991a), and Lake Åsa (Björck et al. 1991a, 1993). A survey of the thickness of lake sediments and presence of tephra layers was also carried out in a group of ten lakes to study the evolution of the deglaciation process on the Peninsula (Björck \& Zale 1996, Björck et al. 1996). According to these studies, the deglaciation of Byers Peninsula began c. $5000{ }^{14} \mathrm{C}$ years BP (c. 5700 cal yr BP) along a west-east gradient, although Sugden \& Clapperton (1986) pointed to a regional deglaciation in the South Shetland Islands starting at c. $9500{ }^{14} \mathrm{C}$ years BP (c. 10700 cal $\mathrm{yr}$ BP) and more recently Watcham et al. (2011) identified deglaciation between c. 11000 and 9000 cal yr BP. Previously, Mäusbacher et al. (1989) suggested that deglaciation occurred between 5500 and $5000{ }^{14} \mathrm{C}$ years BP (6250-5700 cal yr BP) on King George Island, and
Ingólfsson et al. (2003), in a review of palaeolimnological studies of the Antarctic Peninsula region, concluded that the transition from glacial to interglacial conditions was complete by c. $6000{ }^{14} \mathrm{C}$ years BP (c. $\left.6650 \mathrm{cal} \mathrm{yr} \mathrm{BP}\right)$. In this review, the Byers Peninsula was considered to be one of the ice-free areas with the latest date of glacial retreat in the region (according to Björck et al. 1996). At present, the front of the Rotch Dome glacier, located at the east end of the Peninsula, is still receding and the youngest lakes are around 400-500 years old (Björck et al. 1996). Nevertheless, Björck et al. (1996) suggested that the diamicton representing the deglaciation of these lakes may have not been reached during coring and therefore their deglaciation ages should be considered as minimum ages.

The presence of macrofossils such as aquatic mosses throughout a sedimentary record provides an excellent opportunity to develop a precise, high-resolution chronology using Accelerator Mass Spectrometry (AMS) dating; such is the case of the lakes studied from Byers Peninsula. Subsequent correlation of AMS dating against tephra layers, also present in these lakes, provide independent physical stratigraphic markers that can help correlate dates between different sediment records (Hodgson et al. 2004). However, radiocarbon dates from tephra horizons may represent the timing of volcanic eruption but not necessarily that of ash deposition to the lake, due to secondary redeposition of tephra from nearby ice sheet and catchment sources (Lee et al. 2007). The potential for such secondary processes is high in 

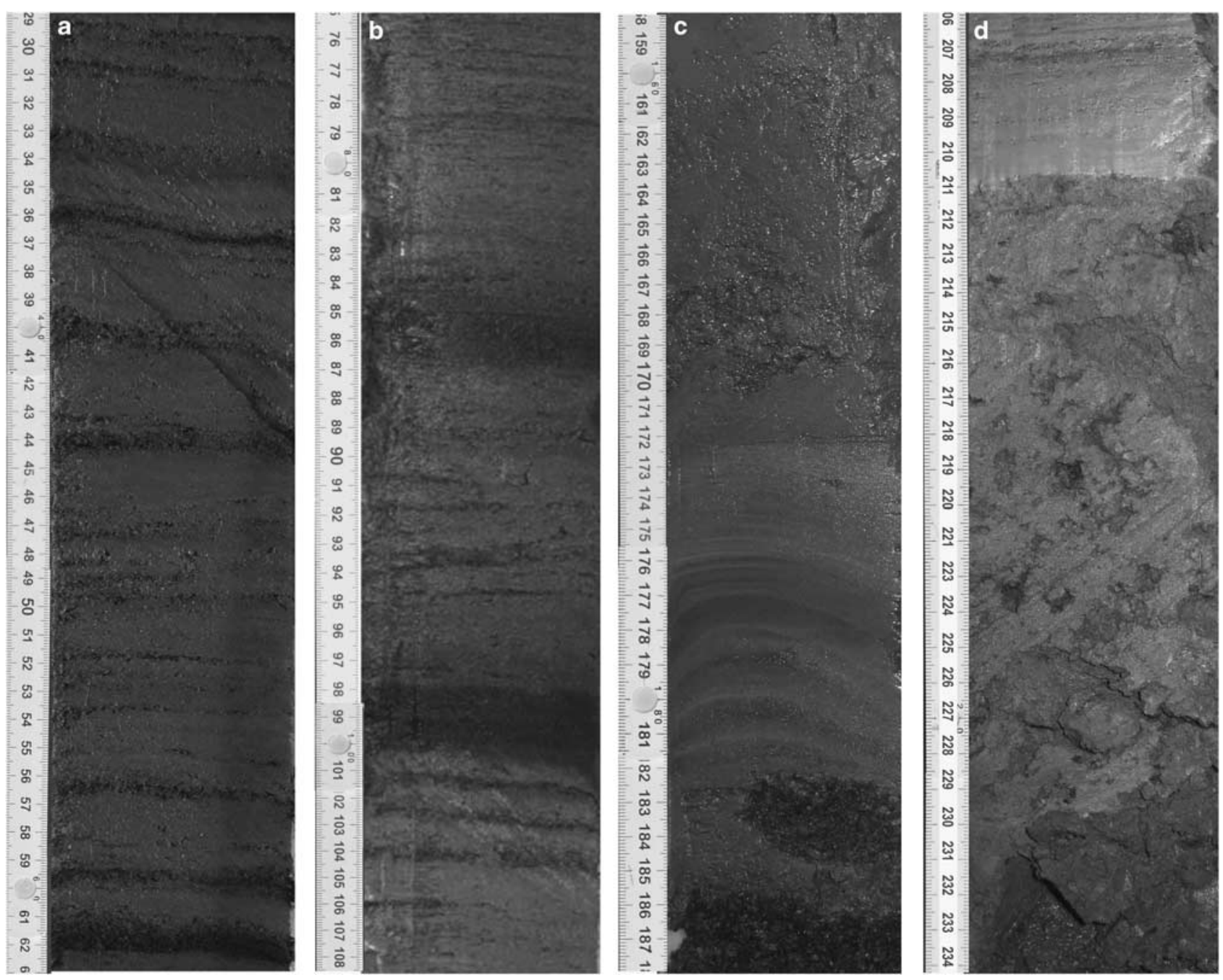

Fig. 2. Characteristic sections of the sedimentary record of Limnopolar Lake (composite depth scale): a. alternation of bulk sediments and moss layers, b. the main two tephra layers, c. the abrupt depositional event, and d. diamicton-glacial till sediment.

Byers Peninsula lakes due to ongoing local deglaciation (i.e. the Rotch Dome).

The present study aims to provide a description of the chronostratigraphy, mineralogy and elemental chemical composition, magnetic susceptibility and tephra layers of the complete post-glacial sedimentary record of Limnopolar Lake (Byers Peninsula, Livingston Island). These results will form the base for ongoing palaeolimnological studies of long sediment cores from this lake, as well contributing to the knowledge of the glacial history and deglaciation processes in the South Shetland Islands and, hence, of the history of climate in Antarctica.

\section{Site description}

Limnopolar Lake $\left(62^{\circ} 38^{\prime} 15^{\prime \prime} \mathrm{S}, 61^{\circ} 06^{\prime} 30^{\prime} \mathrm{W}\right)$ is located on the central plateau of Byers Peninsula in the western part of Livingston Island (South Shetland Islands, Fig. 1). This peninsula forms one of the largest ice-free areas in Maritime Antarctica, with a high number of water bodies with seasonal ice cover (Toro et al. 2007). Figure 1 shows the bathymetric map of the lake, accompanied by morphometric data. The lake is ultraoligotrophic (conductivity: $51-80 \mu \mathrm{S} \mathrm{cm}^{-1}$; $\mathrm{PO}_{4}$ : $\left.0.03-0.09 \mu \mathrm{Ml}^{-1} ; \mathrm{NO}_{3}+\mathrm{NO}_{2}: 0.11-0.32 \mu \mathrm{Ml}^{-1}\right)$ and is icecovered except for 2-3 months during the summer. The watershed is bare, with small scattered patches of mosses and lichens in wet areas, and an active layer over permafrost down to $70-90 \mathrm{~cm}$ depth. This active layer is composed of lithosol that originated from shattered rock fragments produced by periglacial processes, weathering and erosion of Upper Jurassic to Lower Cretaceous marine sediments, volcanic and volcaniclastic rocks (López-Martínez et al. 1996). The main inlet of the lake is a stream that crosses the whole watershed, but surface water runoff also contributes significantly with inputs to the lake during snow pack melt and the permafrost active layer thaw period. A large 
Table I. a. Fallout radionuclide concentrations in Limnopolar Lake sediment core LIM03/1. b. ${ }^{210} \mathrm{~Pb}$ chronology of Limnopolar Lake sediment core LIM03/1.

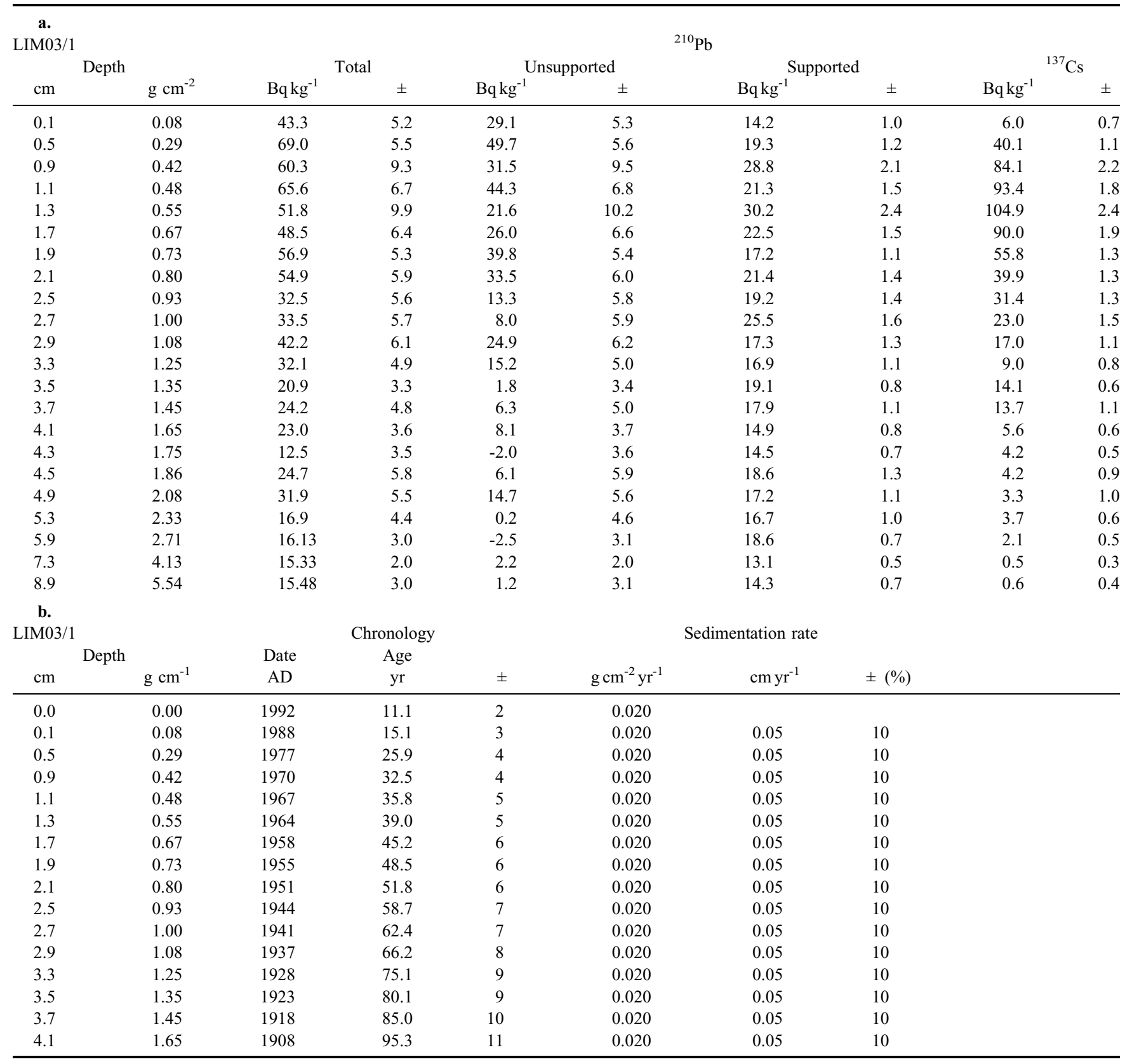

proportion of the lake bottom is covered by a patchy carpet of the moss Drepanocladus longifolius (Mitt.) Paris.

\section{Methods}

The survey was conducted during the summers of 2003-04 and 2008-09. Eight cores were collected from the deepest part of the lake during the period when the lake was ice covered, using an ice-drill to make holes. In December 2003 five short surface sediment cores (LIM03/1-5; from
20-57 cm long) were retrieved using a Glew-type gravity corer and in November 2008 three series of two overlapping long cores (LIM08-AC/DE/BF) were recovered using a UWITEC $^{\circledR}$ piston corer. The longest short core (LIM03/1) was sliced in situ at $2 \mathrm{~mm}$ intervals down to $10 \mathrm{~cm}$ and in $5 \mathrm{~mm}$ sections below this depth, and stored in Whirl-Pak bags in the dark at $4^{\circ} \mathrm{C}$. The long cores were extruded after coring, with the help of a small hydraulic hand pump (UWITEC ${ }^{\circledR}$ ), cut into $60 \mathrm{~cm}$ long sections and stored in the dark at $4^{\circ} \mathrm{C}$ until lab analysis. 

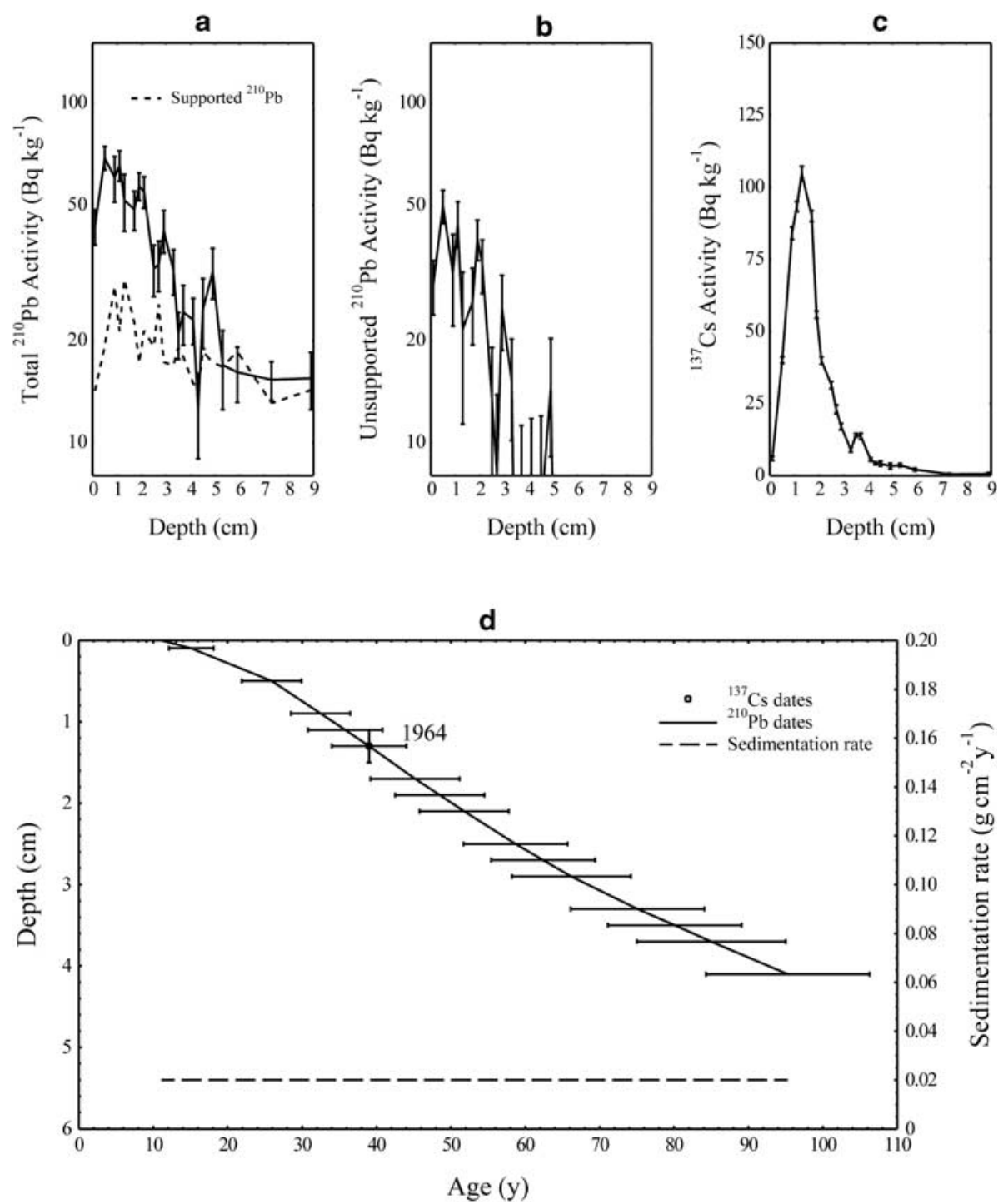

Fig. 3. Fallout radionuclides in the Limnopolar Lake sediment core LIM03/1 showing a. total and supported ${ }^{210} \mathrm{~Pb}$, b. unsupported ${ }^{210} \mathrm{~Pb}$, c. ${ }^{137} \mathrm{Cs}$ concentrations versus depth, d. radiometric chronology of Limnopolar Lake sediment core LIM03/1 with the 1964 depth suggested by the ${ }^{137} \mathrm{Cs}$ record, and the ${ }^{210} \mathrm{~Pb}$ dates and sedimentation rates calculated from the mean gradient of the ${ }^{210} \mathrm{~Pb}$ profile. The ${ }^{210} \mathrm{~Pb}$ dates have been corrected using the ${ }^{137} \mathrm{Cs}$ date as a reference point.

LIM08-D and LIM08-E were selected as master cores, and together with LIM03/1, a composite record was constructed to a sediment depth of $2.34 \mathrm{~m}$. In both long cores two distinct tephra-rich sections were clearly identifiable (Fig. 2b); the base of the lowest one was selected as a stratigraphic marker for the correlation of the two cores. Therefore, the bottom of the composite core to the bottom of the deepest thick tephra layers is based on LIM08-E, whereas from this contact to the top of this composite core $(10 \mathrm{~cm}$ depth), sediments of LIM08-D were used. LIM03/1 has only been used here for chronological purposes (see below), and represents the surface $10 \mathrm{~cm}$ of the core LIM08D which was lost during extrusion.

Sediment samples from cores LIM03/1 and LIM08-D were analysed for ${ }^{210} \mathrm{~Pb},{ }^{226} \mathrm{Ra}$ and ${ }^{137} \mathrm{Cs}$ by direct gamma assay in the University of Liverpool Environmental Radioactivity Laboratory, using Ortec HPGe GWL series well-type coaxial low background intrinsic germanium detectors (Appleby et al.
1986). ${ }^{210} \mathrm{~Pb}$ was determined via its gamma emissions at $46.5 \mathrm{keV}$, and ${ }^{226} \mathrm{Ra}$ by the $295 \mathrm{keV}$ and $352 \mathrm{keV} \gamma$-rays emitted by its daughter isotope ${ }^{214} \mathrm{~Pb}$ following three weeks storage in sealed containers to allow radioactive equilibration. ${ }^{137} \mathrm{Cs}$ was measured by its emissions at $662 \mathrm{keV}$. The absolute efficiencies of the detectors were determined using calibrated sources and sediment samples of known activity. Corrections were made for the effect of self-absorption of low energy $\gamma$-rays within the sample (Appleby et al. 1992).

A total of 25 moss macrofossil samples in cores LIM08-D and LIM08-E, including two overlapping levels, were selected for radiocarbon dating and analysed at the Poznań Radiocarbon Laboratory by ${ }^{14} \mathrm{C}$ accelerator mass spectrometry (AMS). Two additional subsamples of mosses from LIM03/1 were also AMS radiocarbon dated at Beta Analytic Radiocarbon Dating Laboratory.

The chronology for Limnopolar Lake was developed using a combination of ${ }^{210} \mathrm{~Pb}$ and ${ }^{14} \mathrm{C}$ ages. These radioisotopic ages 
Table II. Results of radiocarbon dating with samples from cores LIM08D, LIM08E and LIM03/1 obtained in Limnopolar Lake.

\begin{tabular}{lcclr}
\hline Lab code & Sample code & $\begin{array}{l}\text { Stratigraphic } \\
\text { depth }(\mathrm{cm})\end{array}$ & $\begin{array}{l}\text { Carbon } \\
\text { source }\end{array}$ & $\begin{array}{c}\text { Conventional } \\
\text { radiocarbon } \\
\text { age (yr BP) }\end{array}$ \\
\hline Poz-39062 & LIM08D01 & $13.3-13.5$ & Moss & $555 \pm 30$ \\
Poz-39063 & LIM08D02 & $19.5-19.7$ & Moss & $565 \pm 30$ \\
Beta-299978 & Lim03/1-24.5 & $24.0-24.5$ & Moss & $490 \pm 30$ \\
Poz-39064 & LIM08D03 & $26.2-26.7$ & Moss & $580 \pm 30$ \\
Poz-39066 & LIM08D04 & $33.2-33.4$ & Moss & $850 \pm 30$ \\
Poz-39067 & LIM08D05 & $39.0-39.7$ & Moss & $1045 \pm 35$ \\
Poz-39068 & LIM08D06 & $48.7-49.3$ & Moss & $1280 \pm 30$ \\
Poz-39070 & LIM08D07 & $56.4-57.0$ & Moss & $1445 \pm 30$ \\
Beta-299979 & Lim03/1-57.0 & $56.0-57.0$ & Moss & $1490 \pm 30$ \\
Poz-39071 & LIM08D08 & $65.0-65.5$ & Moss & $1665 \pm 35$ \\
Poz-39072 & LIM08D09 & $75.8-76.4$ & Moss & $1990 \pm 30$ \\
Poz-39073 & LIM08D10 & $85.0-85.3$ & Moss & $2150 \pm 35$ \\
Poz-39074 & LIM08D11 & $94.3-94.8$ & Moss & $2475 \pm 30$ \\
Poz-39075 & LIM08D12 & $97.9-98.3$ & Moss & $2915 \pm 35$ \\
Poz-39076 & LIM08D13 & $102.3-102.5$ & Moss & $2790 \pm 35$ \\
Poz-39077 & LIM08E01 & $104.9-105.4$ & Moss & $2815 \pm 35$ \\
Poz-39255 & LIM08D14 & $100.0-110.5$ & Moss & $3210 \pm 35^{\text {a }}$ \\
Poz-39080 & LIM08E02 & $112.3-112.8$ & Moss & $3440 \pm 35$ \\
Poz-39081 & LIM08E03 & $122.1-122.5$ & Moss & $3625 \pm 35$ \\
Poz-39082 & LIM08E04 & $130.0-130.4$ & Moss & $4150 \pm 35$ \\
Poz-39083 & LIM08E05 & $140.3-140.7$ & Moss & $4770 \pm 40$ \\
Poz-39084 & LIM08E07 & $154.0-154.4$ & Bulk & $10470 \pm 70^{b}$ \\
Poz-39085 & LIM08E09 & $180.5-181.1$ & Bulk & $9100 \pm 70^{b}$ \\
Poz-39086 & LIM08E10 & $188.3-188.5$ & Moss & $4670 \pm 40$ \\
Poz-39087 & LIM08E11 & $190.7-191.2$ & Moss & $4680 \pm 40$ \\
Poz-39088 & LIM08E12 & $200.2-200.6$ & Moss & $5610 \pm 40$ \\
Poz-39090 & LIM08E13 & $205.2-205.4$ & Moss & $6700 \pm 50$ \\
\hline Notes: & & & & \\
\hline
\end{tabular}

Notes:

${ }^{a}$ Repeated (Poz-39077)

${ }^{b}$ Excluded from the model

were used to construct a Bayesian age-depth model with Markov Chain Monte Carlo (MCMC) methods using the R script Bacon (Blaauw \& Christen 2011).

Analyses of the elemental and mineralogical composition of the cores were performed using the Avaatech X-Ray Fluorescence (XRF) core scanner located in the Faculty of Geology (University of Barcelona) and the Siemens D500 $\mathrm{X}$-ray diffractometer from the Jaume Almera Institute of Earth Sciences (CSIC), respectively. XRF core scanner measurements were carried out every $1 \mathrm{~mm}$ under the following working conditions: $10 \mathrm{kV}$ at $15 \mathrm{~s}$ and $20 \mathrm{~mA}$, $30 \mathrm{kV}$ at $30 \mathrm{~s}$ and $20 \mathrm{~mA}$, and $50 \mathrm{kV}$ at $40 \mathrm{~s}$ and $20 \mathrm{~mA}$ in order to obtain statistically significant results. All elemental curves are expressed as counts per second (cps). Although 20 chemical elements were identified, only $12(\mathrm{Al}, \mathrm{Si}, \mathrm{Cl}$, $\mathrm{K}, \mathrm{Ca}, \mathrm{Ti}, \mathrm{Mn}, \mathrm{Fe}, \mathrm{Co}, \mathrm{Cu}, \mathrm{Sr}$ and $\mathrm{Zr}$ ) had enough counts to be considered statistically significant. X-ray diffraction (XRD) samples were obtained every $2 \mathrm{~cm}$, dried for $24 \mathrm{~h}$ at $60^{\circ} \mathrm{C}$ and manually ground in an agate mill. The X-ray diffractometer was equipped with a graphite monochromator and operated with a $\mathrm{Cu} k \alpha$ source at $40 \mathrm{kV}$ and $30 \mathrm{~mA}$. The identification and quantification of the different mineralogical species present in the crystalline fraction were carried out following a standard protocol (Chung 1974).

Determinations of magnetic susceptibility (MS) were performed on cores that were split lengthwise by means of an automated GEOTEK Multisensor Core Logger (MSCL) from the Core Physical Properties Laboratory of the IGME (Galán et al. 2007). The MS estimates the concentration of magnetizable mineral per unit volume (Volume Susceptibility, $10^{-5}$ SI units) of sediment and were carried out using a MS2E1 Bartington spot-reading sensor. MS measurements were performed at $1 \mathrm{~cm}$ intervals.

Two approaches were employed to detect tephra layers in the piston core: tephra horizons were detected by the MS peaks and the most pronounced ones were verified with scanning electron microscopy (SEM). Not all MS peaks corresponded to tephra layers; SEM verifications indicated that some were reworked volcaniclastic material. Most probably there are very thin tephra layers that were not identified, as SEM verification of MS peaks was not carried out systematically. Piston core tephra samples were cleaned ultrasonically, and glass shape and size were observed microscopically. More than 100 randomly selected glass shards from each sample were mounted in epoxy resin, polished using diamond paste and carbon coated. The geochemical composition of individual tephra glass shards was analysed using an automated JEOL JXA-8900R electron microprobe at Seoul National University operated with an accelerating voltage of $15 \mathrm{kV}$, a probe current of $10 \mathrm{~mA}$, and a focused beam diameter of $5 \mu \mathrm{m}$.

In order to compare our results with published data from other sources, previously published ages of tephra horizons in the Antarctic Peninsula region (Björck et al. 1991a) were calibrated using the SHCal04 curve for the Southern Hemisphere (McCormac et al. 2004) assuming a typical error of $\pm 110 \mathrm{yr}$ for conventional ${ }^{14} \mathrm{C}$ dating.

Redundancy Analysis (RDA) of the XRF core scanner and XRD datasets was performed using the "Vegan" package (Oksanen et al. 2012) for R project free software (R Development Core Team 2012; http://www.r-project. org/). RDA was employed on XRD and XRF core scanner datasets to determine the provenance of the chemical elements. Each mineralogical species can be understood as a "compendium" of geochemical elements and, therefore, the XRD dataset was used as a constraining matrix.

$\mathrm{RDA}$ requires two datasets with the same number of samples. As the XRD and XRF core scanner datasets contained different numbers of samples (XRD samples were taken every c. $1.5 \mathrm{~cm}$ whereas the XRF core scanner measured samples every $1 \mathrm{~mm}$ ) and they had different thickness (XRD samples were between 0.5 and $1.0 \mathrm{~cm}$ whereas XRF core scanner samples were $1 \mathrm{~mm}$ ), the XRF core scanner dataset was resampled to the XRD dataset sampling interval. The thickness of every XRD sample was measured and mean values of all XRF core scanner samples that were located within each XRD sample were calculated. 

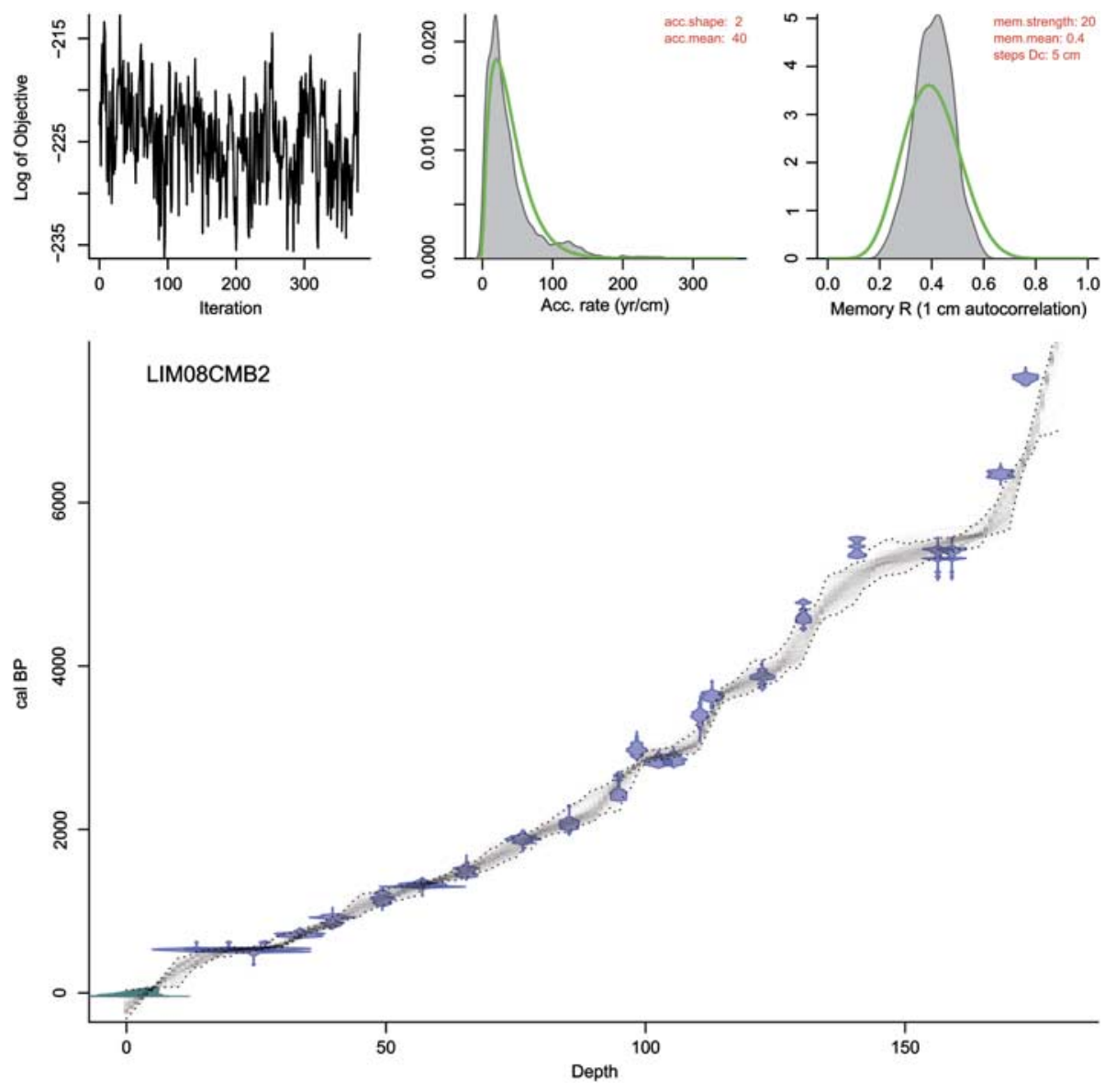

Fig. 4. Age/depth model, including all chronostratigraphic horizons used in model construction. Green symbols are ${ }^{210} \mathrm{~Pb}$ CRS ages, with errors, while blue symbols represent probability distributions of the calibrated ${ }^{14} \mathrm{C}$ AMS dates. The shaded region of the age/depth model shows the ranges and error limits of the model permutations.

\section{Results}

\section{Sedimentary stratigraphy}

According to the main sedimentological features, two main lithological units can be identified (Fig. 2):

- Unit 1 (2080-2340 mm) is made up of very poorly sorted sediments, ranging from massive grey bluish clays to decimetre-scale volcanic boulders (Fig. 2d). The contact of Unit 1 with Unit 2 is subhorizontal and showed an abrupt colour change. Similar material has also been identified under the main ice sheets present in the Byers Peninsula and can be interpreted as a till deposit. Additional evidence of having reached the basal diamicton in the lake basin was the destruction of the core catcher due to the presence of decimetre-sized volcanic clasts.

- Unit 2 (100-2080 mm) corresponds to the lacustrine infill of Limnopolar Lake and it is composed of a decimetre to millimetre alternation of light brownish massive clays and silty clay layers, and dark brownish moss layers (Fig. 2a). This alternation is well marked in the uppermost third of the composite core whereas it is less clear in the lower two thirds of the lacustrine record. There were a number of tephra layers intercalated within this alternation. These tephra layers were composed of either decimetre-scale, coarse, well-sorted and massive sandy layers, such as that found at the $187 \mathrm{~cm}$ composite core depth, or millimetre-scale, fine silty clay layers, such as those located at composite core depths $85.0-87.4 \mathrm{~cm}$ and 96.7-100.8 cm (Fig. 2b). From $155 \mathrm{~cm}$ to $187 \mathrm{~cm}$ composite core depth (Fig. 2c), the sediments of Limnopolar Lake are composed of massive light brownish clays and silty clays without any evidence of moss layers. The upper and lower contacts of this decimetre-scale massive layer are subhorizontal and abrupt.

Fig. 5. Stratigraphic plots of magnetic susceptibility $\left(10^{-5}\right.$ S.I.) and accumulation rates $\left(\mathrm{cm}^{*} \mathrm{yr}^{-1}\right)$, XRF (counts per second, cps) and DRX (\% of total weight) core scanner data of the main chemical elements and minerals, and tephra layers (SEM-confirmed tephra represented by black lines and non-confirmed tephra represented as dashed lines) in the Limnopolar Lake sedimentary record, including lithostratigraphic units and zone boundaries. 
a XRF core scanner dataset

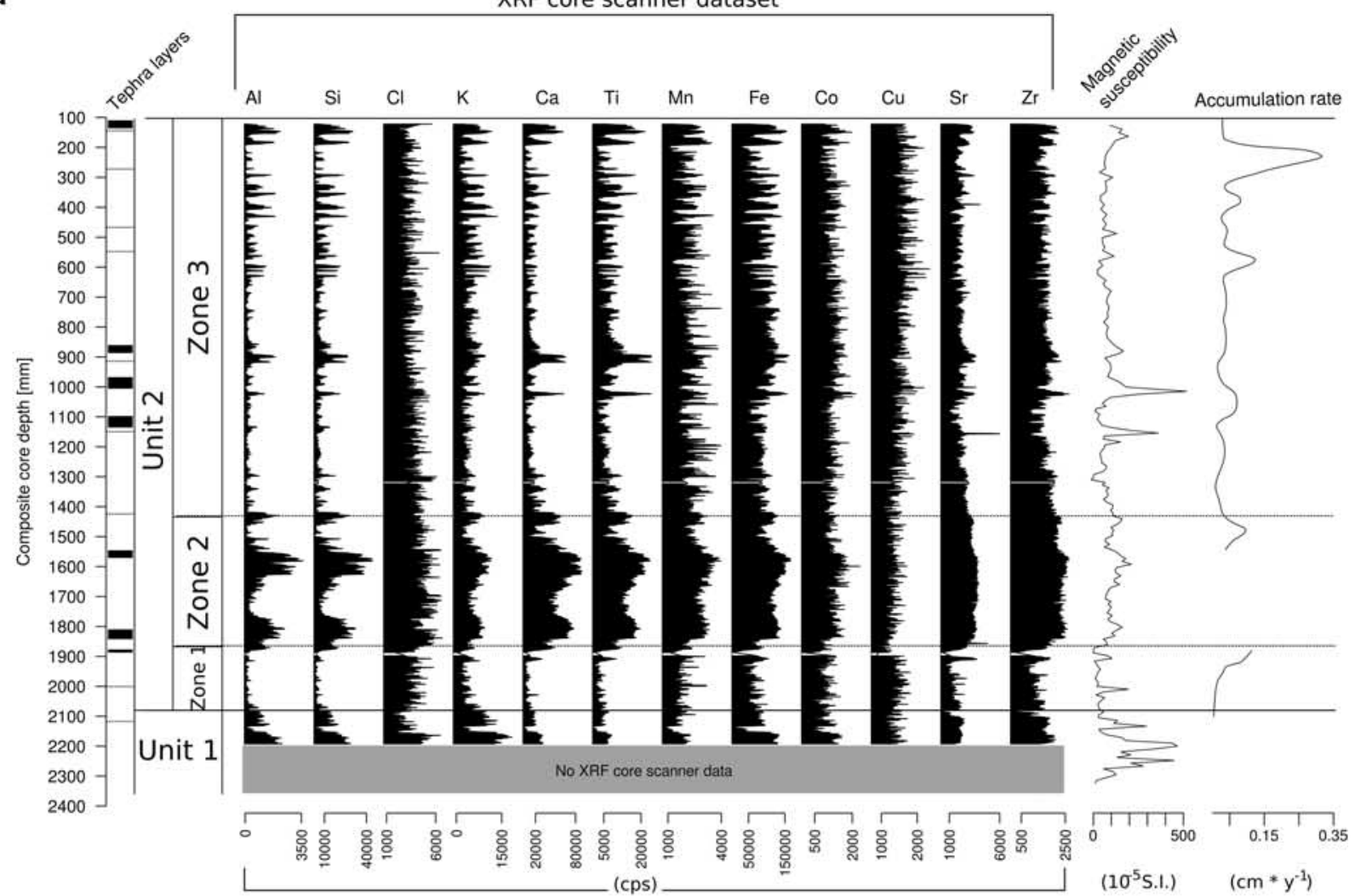

b

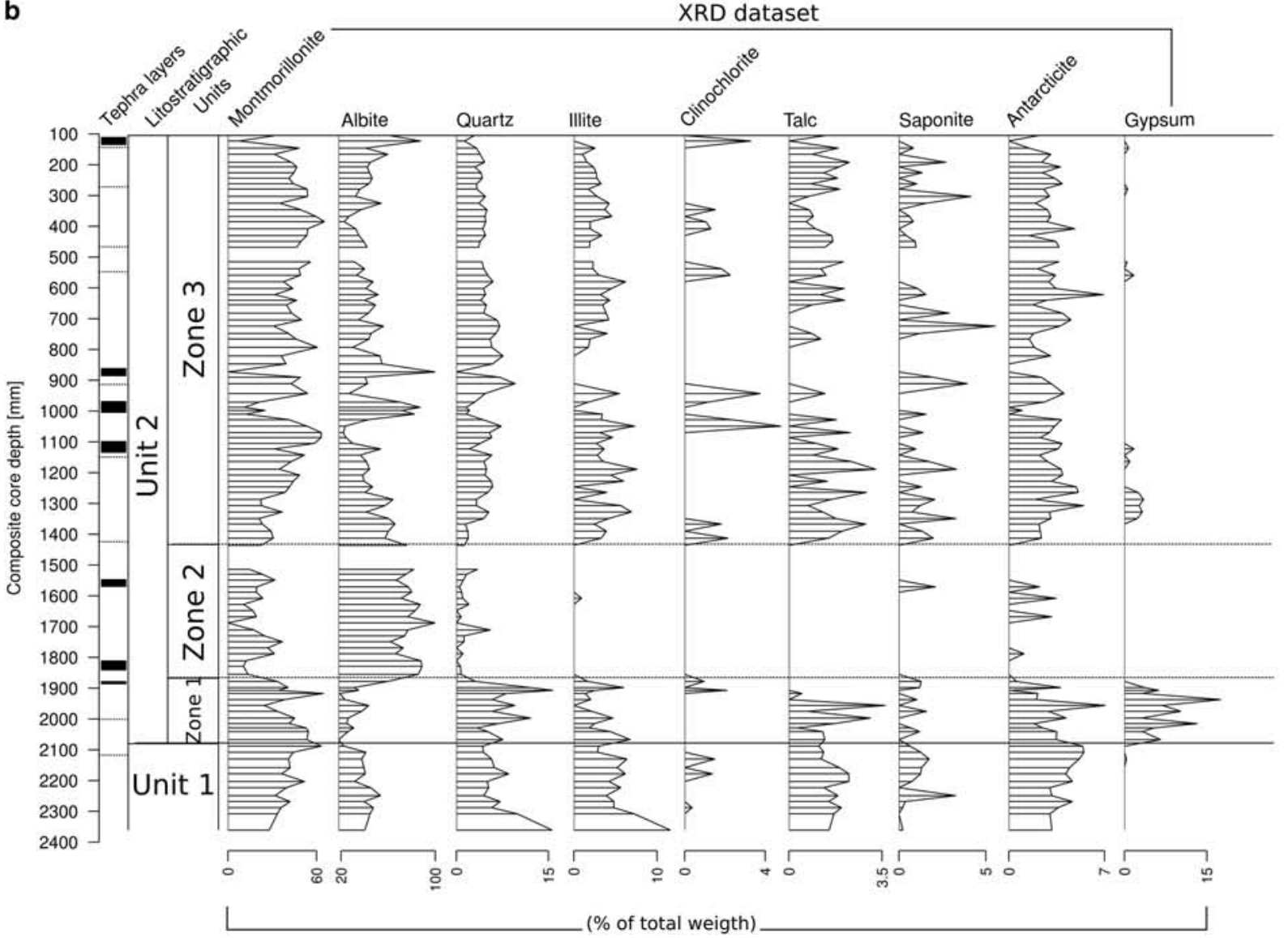




\section{Dating results and age-depth model}

Detailed radiometric results for core LIM03/1 are given in Table Ia. Relatively high levels of fallout ${ }^{210} \mathrm{~Pb}$ and ${ }^{137} \mathrm{Cs}$ were detected in the core (Fig. $3 \mathrm{a}-\mathrm{c}$ ). Total ${ }^{210} \mathrm{~Pb}$ activity reached equilibrium with that of the supporting ${ }^{226} \mathrm{Ra}$ at a depth of around $5 \mathrm{~cm}$ (Fig. 3a). Unsupported ${ }^{210} \mathrm{~Pb}$ activity (Fig. 3b) declined irregularly with depth, although since the overall trend was more or less exponential it appears that there was no systematic change in the accumulation rate during the period of time spanned by the ${ }^{210} \mathrm{~Pb}$ record. The ${ }^{137} \mathrm{Cs}$ activity (Fig. 3c) had a distinct peak in the $1.2-1.4 \mathrm{~cm}$ section that most probably records the 1964 fallout maximum in the Southern Hemisphere from the atmospheric testing of nuclear weapons. ${ }^{210} \mathrm{~Pb}$ dates calculated using the CRS model (Appleby \& Oldfield 1978) placed 1964 at a depth of about $2.3 \mathrm{~cm}$, significantly below the depth suggested by the ${ }^{137} \mathrm{Cs}$ record. Two possible reasons for the discrepancy are a significant decline in the ${ }^{210} \mathrm{~Pb}$ supply rate in recent decades, or the loss of a small amount of sediment from the top of the core during coring.

Although the detailed CRS model calculations suggest significant fluctuations in the sedimentation rate, in view of the large uncertainties associated with these calculations, ${ }^{210} \mathrm{~Pb}$ dates for the core have been calculated using the mean sedimentation rate of $0.020 \pm 0.002 \mathrm{~g} \mathrm{~cm}^{-2} \mathrm{yr}^{-1}\left(0.052 \mathrm{~cm} \mathrm{yr}^{-1}\right)$ determined from the mean exponential gradient of the ${ }^{210} \mathrm{~Pb}$ profile, using also the ${ }^{137} \mathrm{Cs}$ date as a reference point. The results of these calculations, which support the notion of a small loss of sediment from the top of the core, are shown in Fig. 3d and given in detail in Table Ib. In LIM08D1B the concentrations of fallout ${ }^{210} \mathrm{~Pb}$ and ${ }^{137} \mathrm{Cs}$ were all below the minimum level of detection and it was not possible to date sediments in this core by this methodology.

Table II shows the results of radiocarbon dating, with 25 samples that were analysed from piston cores (14 in LIM08D and 11 in LIM08E), and two samples from the surface core (LIM03/1). The ${ }^{14} \mathrm{C}$ dates were in chronological order with the exception of one reversal in each core segment $(98.3 \mathrm{~cm}$ of composite core depth and found in LIM08D and $140.7 \mathrm{~cm}$ of composite core depth and located at LIM08E). Moreover, an unexpected, more recent aged layer was suggested in the combined core (at $24.5 \mathrm{~cm}$ in LIM03/1 section).

As a first step, age/depth models were constructed separately for each of the three overlapping core sections in order to validate the correlation of the three cores as well as to investigate the possibility that sedimentation rates varied between the core sections. These models (data not shown) indicated a high similarity of sedimentation rates and inflection points in the independent models of each of the three sections, and confirmed the validity of the core correlations determined from visually matching tephra and moss layers.

Two ${ }^{14} \mathrm{C}$ dates of sediments (without mosses) within the massive light brown clay layer located between $187.8 \mathrm{~cm}$ and $151 \mathrm{~cm}$ composite core depth returned ages that greatly

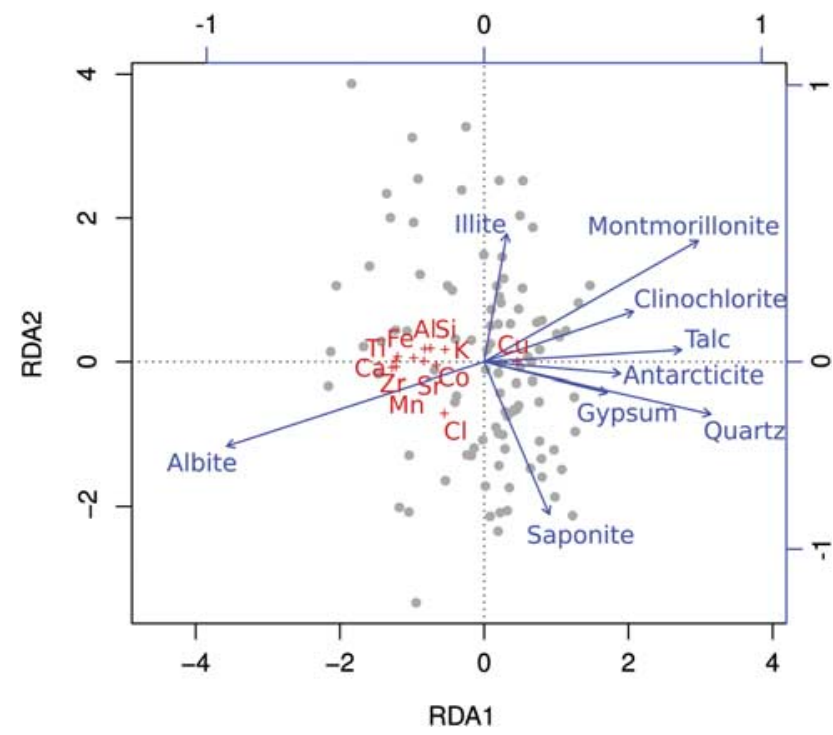

Fig. 6. RDA biplot in the plane defined by the first two eigenvectors of the XRD and XRF datasets of samples analysed for elemental and mineralogical composition in cores LIM08D and LIM08E.

exceeded those above and below the event boundaries. These anomalous ${ }^{14} \mathrm{C}$ ages were therefore rejected because of their low $\mathrm{C}$ content in the samples $(0.4 \mathrm{mg}$ and $0.25 \mathrm{mg})$ and the massive nature of this layer, and excluded from the model. The sediment record was assumed to be isochronal over these depths during age-depth model construction.

The master age model (Fig. 4) was therefore based on $25{ }^{14} \mathrm{C}$ ages calibrated using the SHCal04 curve for the Southern Hemisphere (McCormac et al. 2004) and 16 age horizons taken from the ${ }^{210} \mathrm{~Pb}$ dating model. The "Bacon" based chronological model was constructed in $5 \mathrm{~cm}$ segments (i.e. 37 segments) using the following parameters: mean accumulation $=40 \mathrm{yr} \mathrm{cm}^{-1}$, accumulation shape $=2$, memory strength $=20$, memory mean $=0.4$. Models were run with 4680000 iterations from which every 195th iteration was kept, and several model runs were performed in order to ensure that the results were stable. The mean $95 \%$ confidence interval of the model was 271 years, with a maximum of 1615 years in the bottom section (i.e. $212 \mathrm{~cm}$ ).

The $2.34 \mathrm{~m}$ combined core collected in Lake Limnopolar consisted of three overlapping parts (LIM03/1, LIM08D and LIM08E). Dating techniques gave a Holocene age for the oldest moss macrofossil of $6700 \pm 50 \mathrm{yr}$ BP $(7510 \pm 80$ cal yr вP) from which the chronological model inferred a basal age of the sedimentary record of $c .8300 \mathrm{cal} \mathrm{yr} \mathrm{BP.}$ The mean accumulation rate was $0.050 \mathrm{~cm} \mathrm{yr}^{-1}$ (Fig. 5), which is in agreement with that from the ${ }^{210} \mathrm{~Pb}$ CRS model for more recent years. Three different periods with higher accumulation rate were found: a) $530-545 \mathrm{cal}$ yr BP: highest accumulation rate $\left(0.345 \mathrm{~cm} \mathrm{yr}^{-1}\right)$, matching with frequent and high moss growth, b) $1320-1350 \mathrm{cal}$ yr BP: $0.130 \mathrm{~cm} \mathrm{yr}^{-1}$, 


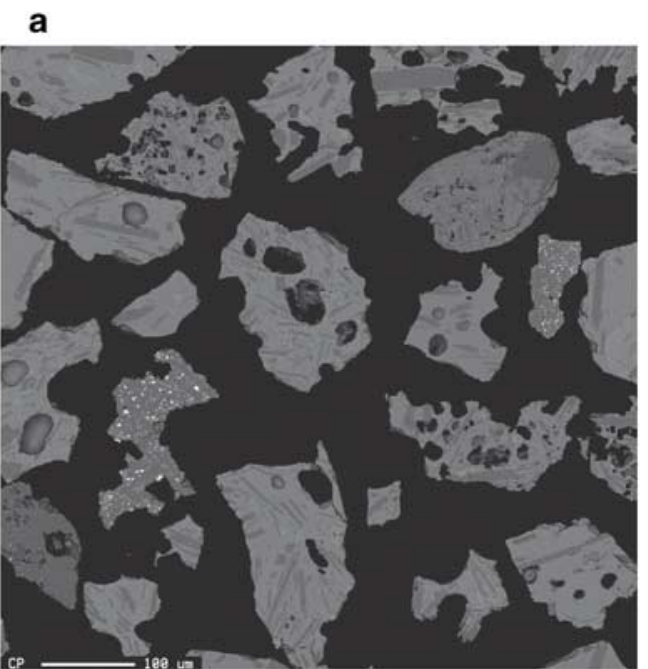

b

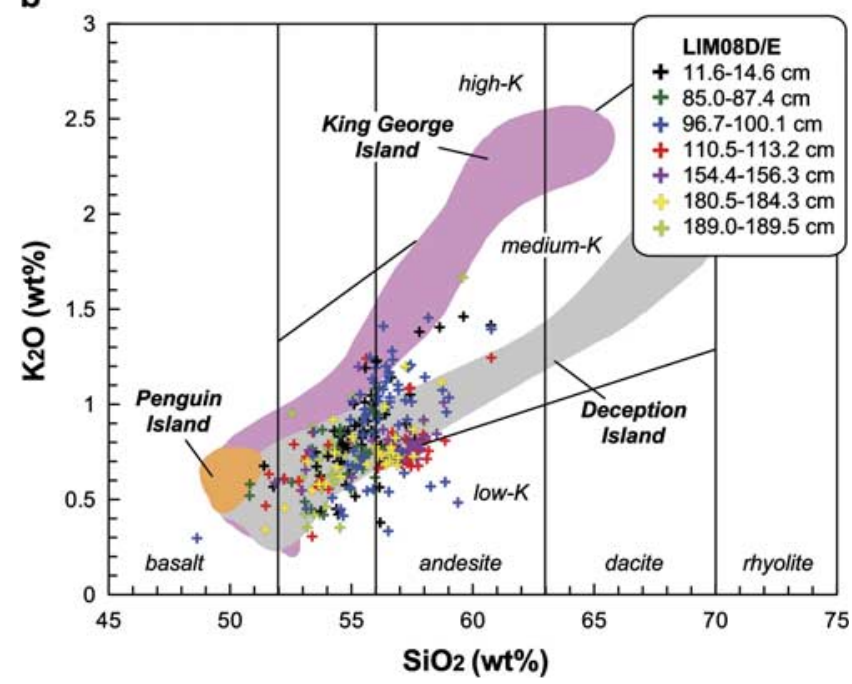

Fig. 7. a. BSE (backscattered electron) image of volcanic glass shards separated from the surface sediment of LIM08D core. Note the vesiculated and blocky basaltic shards with euhedral microphenocrysts of plagioclase. b. Bivariate plot showing $\mathrm{SiO}_{2}$ vs $\mathrm{K}_{2} \mathrm{O}$ for tephra in the lake core sediments (diagram after Fretzdorff \& Smellie 2002). $\mathrm{SiO}_{2}$ and $\mathrm{K}_{2} \mathrm{O}$ are wt.\% on an anhydrous basis.

and c) 2885-3015 cal yr BP: $0.071 \mathrm{~cm} \mathrm{yr}^{-1}$. Accumulation rates were also higher than mean values just above and below the abrupt event; however, this could be an artefact of the age/ depth model construction.

\section{Mineralogical $(X R D)$ and geochemical $(X R F)$ composition of the sediments}

X-ray diffraction showed that Limnopolar Lake sediments were composed of clays (montmorillonite, illite, chlorite, talc and saponite), felspars (albite), chlorides (antarcticite), sulfates (gypsum) and quartz (Fig. 5). Montmorillonite and albite were the two most important mineral species present (mean values of $37.4 \pm 14.8 \%$ and $49.8 \pm 19.8 \%$ by weight, respectively). Unit 1 was composed (up to $80 \%$ of the total mineral composition) almost exclusively of these two minerals. Three mineralogical zones were identified in Unit 2: Zone 1, between the base of this zone and $187.5 \mathrm{~cm}$ composite core depth, with the lowest proportions of albite (mean: $31.3 \mathrm{wt} . \%$ ) and the highest of gypsum (mean: $5.7 \mathrm{wt} . \%$ ) and antarcticite (mean: $1.1 \mathrm{wt} . \%$ ); Zone 2, located between $187.5 \mathrm{~cm}$ and $154.5 \mathrm{~cm}$ composite core depth and almost exclusively made up of albite (mean: 76.5 wt.\%) and montmorillonite (mean: 21.0 wt.\%); and Zone 3, from $154.5 \mathrm{~cm}$ to the top of the composite core, with roughly constant mineralogical composition. The mineralogical species present in Limnopolar Lake sediments are related to the volcaniclastic material of the catchment (albite, illite and quartz), its chemical alteration (montmorillonite, saponite, talc and chlorite) and to salt input due to marine sea spray (gypsum and antarcticite).

The XRF core scanner data also reflects the different mineralogical composition of the lithological units and zones previously described (Fig. 5). Unit 1 is characterized by the decreasing upwards trend of almost all chemical elements and by being the richest in $\mathrm{K}$ of the whole sequence. Zone 1 of Unit 2 shows a clear dominance of heavy elements, such as $\mathrm{Zr}, \mathrm{Sr}, \mathrm{Cu}$ and $\mathrm{Co}$ compared to light ones ( $\mathrm{Al}, \mathrm{Si}, \mathrm{Ca}$ and $\mathrm{Ti})$. Zone 2 of Unit 2 is clearly defined by two gentle increases and decreases of all chemical elements except for $\mathrm{Cl}$. These two fluctuations are more visible in the light elements than in the heavy ones. Zone 3 of Unit 2 is characterized by a series of abrupt peaks of almost all chemical elements. This peaking behaviour is clearly driven by the alternation of clay (high cps) and moss (low cps) layers.

\section{Statistical treatment of the datasets: Redundancy Analysis (RDA)}

The plot of the XRD and XRF samples in the plane defined by the first two eigenvectors of the RDA allowed us to identify the main mineralogical species sources of the chemical elements (Fig. 6). All measured chemical elements, except for $\mathrm{Cu}$ (associated with talc) and $\mathrm{Cl}$ (associated with saponite), are derived from albite. Therefore, fluctuations in the XRF core scanner dataset reflect changes in the input of volcaniclastic material (either tephras or reworked volcaniclastic material previously deposited in the catchment) to the lake.

\section{Tephras}

As previously reported for the Byers Peninsula, several distinct tephra layers could be visually recognized in lake sediments. In the composite piston core 16 possible tephra layers were recognized based on visual observations and MS values (Fig. 5). Seven of them were confirmed with SEM analyses: 11.6-14.6, 85.0-87.4, 96.7-100.1, 110.5-113.2, 
154.4-156.3, 180.5-184.3 and 189.0-189.5 cm composite depth (Fig. 7b). The thickest two of these layers (85.0-87.4, 96.7-100.1 cm) were present in both LIM08E and LIM08D cores. They were located in Zone 3 of Unit 2, with a thickness of $18 \mathrm{~mm}$ in the upper and $33 \mathrm{~mm}$ in the lower section. Some tephra layers were macroscopically invisible but could, nevertheless, be recognized by their magnetic or geochemical properties. Electron microprobe analyses of glass shards from the ash horizons are presented in Fig. 7a. Most common were brown to black, blocky, non-vesicular to highly vesicular glass shards. The analysed tephra samples showed a wide range in composition from basalt to andesite (c. 49-61 wt.\% $\mathrm{SiO}_{2}$ ) magmas similar to medium-K tholeiitic series, although there was a predominance of basaltic andesites and andesites. Analysed glasses from each horizon showed mean $\mathrm{SiO}_{2}$ contents between 54.4 and 56.6 wt.\%. All possible tephra layers detected by the different approaches are recorded in Fig. 5, where tephras confirmed by SEM are indicated by black bars.

\section{Discussion}

One of the most striking features of the Limnopolar Lake sediments is the fine alternation of clays and silty clays, and of Drepanocladus longifolius moss layers. This moss has been described from King George Island as well as other locations in Antarctica and South America (Li et al. 2009), and it is present in other lakes in Byers Peninsula (e.g. Chester Lake, Midge Lake; personal observation). This moss is a pan-south-temperate species that grows submerged in shallow lake areas and develops during the summer. The annual growth rate and longevity of Drepanocladus longifolius are related to water temperature and light intensity according to observations and a review of data from Antarctica (Li et al. 2009). Therefore, its presence in the core sediments might be interpreted either as an indication of relatively warmer air temperatures and hence less cold lake water conditions that would cause shorter ice cover periods reducing them to the winter alone, and/or relatively dry conditions as snow deposited on the ice cover could drastically reduce the light reaching the lake bottom. It is also possible that the core is simply recording changes in the spatial patchiness of the moss growing on the bottom of the lake over time. The lithological alternation could therefore represent either periodic changes between cold (clay and silty clay layers) and warm (moss layers) conditions or changes in the spatial coverage of benthic mosses. According to the chronological model these possible periodic climate fluctuations would take place at decadal timescales.

Our dating results have avoided the limitations that were inherent in some previous palaeolimnological studies from the South Shetland Islands, since all radiocarbon ages were based on moss layers, and bulk sediment dates were not used. This is reinforced by the older ages obtained by the only two bulk sediment samples taken from strata where no moss layers were present (see Table II). Moreover, the number of ${ }^{14} \mathrm{C}$ samples as well as the high-resolution stratigraphic coverage exceeds those in most previous studies from the South Shetland Islands, which implies a better constrained and more reliable age/depth model. The possible reservoir effect of the lake water is considered to be negligible for two reasons: first, water inputs to the lake are mainly fed by snow melting surface water and precipitation because the permafrost in the watershed avoids the input of old contaminated groundwater (Björck et al. 1991b), and second, because when the ${ }^{210} \mathrm{~Pb}$ curve is extended downwards to the first ${ }^{14} \mathrm{C}$-dated moss layer, the age closely approximates that of the radiocarbon age. Other studies from the South Shetland Islands have also recorded modern or near-modern surface ages (Watcham et al. 2011). Therefore, the summer melting of the lake ice enables the aquatic organisms to fix dissolved inorganic carbon (DIC) from atmospheric $\mathrm{CO}_{2}$, maintaining a good ${ }^{14} \mathrm{C}$ equilibrium (Hodgson et al. 2001, 2004).

Since no significant changes were detected in the sedimentation rate at large timescales (i.e. multi-centennial) during the last $5000 \mathrm{yr}$, we can assume a low rate of hydromorphological change in the catchment. At shorter timescales (i.e. centennial scale), fine-tuned changes in lake sedimentation rate linked to Ti concentration could be related to changes in surface hydrology, which could modify lake productivity. However, sedimentation rates were not related to the presence (or absence) of moss layers and it seems clear that the Lake Limnopolar sedimentation rate changes are linked to the volcaniclastic inputs to the lake, and not to changes in the lake productivity.

The massive light brown clays and silty clays identified in the core from 155 to $187 \mathrm{~cm}$ composite core depth (Fig. 2c) have clear and distinctive geochemical and mineralogical (Zone 2 of Unit 2) signatures, suggesting that the sedimentary process that triggered the input and accumulation of these sediments was different from those that ruled the deposition of the rest of the lacustrine sediments. According to the chronological model, this event took place around $5400 \mathrm{cal} \mathrm{yr} \mathrm{BP.} \mathrm{High} \mathrm{sediment} \mathrm{delivery} \mathrm{around}$ this period has also been documented in Long and Yanou lakes, and across Fildes Peninsula, suggesting that this was a regional event interpreted as a period of stormier climate owing to the increased presence of sea spray in these coastal lakes (Watcham et al. 2011). Some authors have documented a period of glacial re-advance in the South Shetland Islands area from around $7000 \mathrm{yr}$ BP, persisting even until $5000 \mathrm{yr}$ BP (Hjort et al. 1992). One possibility is that these sediments could be related to the latest period of this glacial re-advance and they would constitute the reworked sediments of a till deposit. It is unlikely that the Rotch Dome ice cap re-advanced up to Lake Limnopolar, as the deposited layer within the lake is quite thin, and possibly it was already quite far from it. It is more probable 
that a small ice cap stationed around the nearby Chester Cone peak could have re-advanced, reaching the lake at the end of this cold period. Another feasible explanation could be linked with abrupt geomorphological processes in the catchment due to the highly dynamic environment of this area (López-Martínez et al. 2012). In Byers Peninsula, most lakes are located in over-deepened basins formed by glacial erosion, interconnected with gentle slopes that form a roughly flat platform. This platform shows a drainage network which results from the successive capturing of glacially excavated catchments and endorheic areas (López-Martínez et al. 1996). An abrupt input of coarse alluvial sediment from a recently captured catchment fed by the ice cap melting sediment-rich waters could generate such a depositional event. In this second hypothesis, these massive sediments would only represent local geomorphological processes, not necessarily linked to regional climate dynamics.

Our tephrachronological results showed reasonable agreement with previous studies. Furthermore, since the tephrachronology proposed by Björck et al. (1991a) relied only on nine ${ }^{14} \mathrm{C}$ ages (five AMS + four conventional), from three different lakes, while our age/depth model used $25{ }^{14} \mathrm{C}$ ages and 16 age horizons from the ${ }^{210} \mathrm{~Pb} \mathrm{CRS}$ model, we believe that our results refine the previous estimated ages of these tephra layers.

Björck et al. (1991a) suggested that typical tephra layers included a sharp lower boundary and a diffuse upper boundary where the tephra graded upwards into a mixture of clays and gyttja. This upper boundary could be explained as an effect of tephra redeposition from the catchment after the eruption. We suspect that this process may span decades, as was found, for example, for AP2, where the concentration of tephra-marker elements ( $\mathrm{Ca}$ and $\mathrm{Ti}$ ) progressively decays from 375 to $325-300 \mathrm{cal}$ yr BP.

Moreover, our findings indicate that all tephra layers cannot be related unequivocally to a volcanic eruption. The average particle size of studied glass shards was about $0.2 \mathrm{~mm}$, suggesting that they originated from the volcanoes located within or around the Antarctic Peninsula (AP) region. In the northern AP region, a number of volcanoes are situated along and parallel to the rifting axis of Bransfield Strait (Tatur et al. 1999). These Quaternary volcanic rocks are mainly basalts and more rarely andesites, compositionally similar to other back-arc basin basalts (Keller et al. 1991). The source for each tephra may be identified by comparing the chemical composition of glass shards with geochemical data from previously published glass geochemistry in the northern AP (Keller et al. 1991, Toms et al. 2004). The analytical results of this study suggest that the geochemical compositions of most glass shards are similar to those from Deception Island (Fig. 7b). This interpretation agrees with previous studies that show Deception Island to be the major source of Quaternary tephra horizons in the northern AP region (Smellie 1990, Björck et al. 1991a, Hodgson et al. 1998, Pallàs et al. 2001).
Thus far, many tephra layers have been reported from lake sediment cores from the South Shetland Islands, as well as from marine sediments in the Bransfield Strait (Matthies et al. 1990, Björck et al. 1991a, Smellie 1999, Willmott et al. 2006) and lake sediments at Beak Island (Sterken et al. 2012). The use of these tephra layers as time markers has been limited by the lack of precise chronologies and incomplete geochemical fingerprinting (Willmott et al. 2006). Most tephra layers from lake sediment cores have been independently dated by radiocarbon dating of moss banks and bulk lacustrine sediment. However, in the earlier studies the lacustrine dates did not provide the best age constraints for the tephra layers because of dating problems including contamination of the radiocarbon pool by old carbon derived from bedrock, penguin/skua guano, and ice/snow melt, or sediment disturbance in shallow lakes due to bottom freezing or oxidation of surface sediments during periods of desiccation (Björck et al. 1991b). Because the tephra layers found in Limnopolar Lake, in lakes on King George Island (Watcham et al. 2011) and Beak Island (Sterken et al. 2012) were mainly based on macrofossil dates, they can be used as effective tools in the correlation of Holocene lake tephra horizons previously reported in the King George Island area, as it is possible to overcome all difficulties previously reported.

Due to their remarkable thicknesses, two tephra horizons are clearly recognized between different lakes from the Byers Peninsula: the thickest one, AP12, is $25 \mathrm{~mm}$ thick in Lake Åsa, $15 \mathrm{~mm}$ in Midge Lake (Björck et al. 1991c) and $33 \mathrm{~mm}$ in Limnopolar; AP10 is $20 \mathrm{~mm}$ thick in Asa and $15 \mathrm{~mm}$ in Midge, while in Limnopolar it is $18 \mathrm{~mm}$ thick.

Our estimate of the age of AP12 in Limnopolar Lake is in good agreement with Björck et al. (1991a) (c. 2800-2870 cal yr BP), although AP10 is slightly younger according to our model (c. $2100 \mathrm{cal}$ yr BP) than previously reported (c. $2520 \mathrm{cal}$ yr BP). Sterken et al. (2012) reported a tephra layer with 1981-2028 cal yr BP and another one with 2260-2329 cal yr BP.

Between both thick layers, a very thin tephra horizon (AP11, c. 1-3 mm thick) has been reported from the other lakes in Byers Peninsula, corresponding to an estimated age of $2600 \mathrm{cal}$ yr BP. In our study, an indistinct MS peak could be observed at $c$. 2255-2380 cal yr BP. Tephra layers AP4, AP6, AP7, AP8 and AP9 have not been previously reported from Byers Peninsula sediments, and our study found no evidence of tephra layers of these ages.

AP5 has been identified as a complex layer, consisting of two or three tephra bands separated by thin layers of clayey gyttja in Lake Åsa, although in nearby Midge Lake and Chester Cone Lake it appears as a single horizon (Björck et al. 1991a). In Limnopolar Lake the MS profile shows two distinct peaks at $c .1080$ and $1295 \mathrm{cal} \mathrm{yr} \mathrm{BP,} \mathrm{which} \mathrm{is}$ very close to the estimated ages for these horizons in $\AA$ sa Lake: 1120 and $1250 \mathrm{cal}$ yr BP.

AP3 has also been reported as a complex layer, with at least two estimated ages: 670 and 710 cal yr BP. 
The Limnopolar Lake MS profile shows a peak at c. 565 cal yr вP, and microscopic observations revealed a tephra layer at $c .650 \mathrm{cal} \mathrm{\textrm {yr }} \mathrm{BP}$.

In contrast, the AP2 tephra level was identified by Björck et al. (1991a) as a single layer in Byers Peninsula lakes with an estimated age of $420 \mathrm{cal} \mathrm{yr}$ BP. In Limnopolar Lake we found a tephra layer aged $410 \mathrm{cal} \mathrm{yr}$ BP and another one aged 505 cal yr BP, both based on geochemical composition (i.e. layers enriched in $\mathrm{Ca}, \mathrm{Ti}, \mathrm{Zr}$ and $\mathrm{Sr}$ ). Both layers are probably linked to the AP2 event, but at least the first one is in very good dating agreement. There is also a Limnopolar Lake MS peak at $c .365 \mathrm{cal}$ yr BP that may be assigned to AP2.

Although tephra AP1 has not been previously reported in Byers Peninsula, we found evidence of an event or possibly a series of nearly synchronous events at this time. Björck et al. (1991a) considered AP1 to have an age of $240 \mathrm{cal} \mathrm{yr} \mathrm{BP,}$ while our geochemical data suggests two tephra layers from Limnopolar at c. 135 and 325 cal yr BP, supported by a MS peak centered at c. $290 \mathrm{cal} \mathrm{yr} \mathrm{BP}$.

This evidence of previously undetected tephra layers in Byers Peninsula lakes (or events not previously detected in Antarctic Peninsula) is also found with older tephra horizons. AP13 has been estimated at $3720 \mathrm{cal}$ yr BP (Björck et al. 1991a) in moss cores from Walker Point (Elephant Island), and a younger tephra layer of 3169-3286 cal yr BP has also been observed (Sterken et al. 2012). In Limnopolar Lake two MS peaks were centred at $c .3520$ and $3705 \mathrm{cal} \mathrm{yr} \mathrm{BP}$, and a tephra layer was identified microscopically at $c .3250 \mathrm{cal} \mathrm{yr} \mathrm{BP.}$ However, it remains unclear whether any of these may be linked to AP13 observed in Walker Point or the tephra reported by Sterken et al. (2012).

Finally, the oldest tephra layer identified in the published tephrachronology is AP14, with an estimated age of $5400 \mathrm{cal} \mathrm{yr}$ BP. It is not clear how this horizon may be linked to tephra layers in Limnopolar Lake, since this age is quite close to that of the massive light brown clays previously described from its sediments. Tephra layers have been identified just after the depositional event (c. $5390 \mathrm{cal} \mathrm{yr} \mathrm{BP),}$ inside the depositional event (c. $5400 \mathrm{cal} \mathrm{yr} \mathrm{BP})$ and also just before the sedimentary event, at $c .5415 \mathrm{cal}$ yr BP. From the MS profile, two peaks were detected synchronously with the sudden event (c. $5400 \mathrm{cal} \mathrm{yr} \mathrm{BP}$ ), as well as a younger (5145 cal yr BP) one. Previously reported layers in Antarctic Peninsula area around this age are the $5200 \mathrm{yr}$ BP layer (Matthies et al. 1990), or the $5.0 \pm 0.07$ ka layer dated by geomagnetic palaeointensity (Willmott et al. 2006).

Furthermore, two additional MS peaks with modelled ages of 5550 and $8285 \mathrm{cal} \mathrm{yr}$ BP were observed. These last two are previously unrecognized events, since no other cores yet retrieved from the Byers Peninsula contain the entire postglacial sediment record, and also appear to be without parallel in the published literature to date. Other MS high values were found in the basal diamicton; however, given the nature of the sediments, we did not consider them when discussing tephra layers.
Although the stratigraphy and chronological position of the major tephra layers enabled us to correlate them with previously published ages for regional tephras from the Deception Island volcano, in some cases it is not clear whether these tephra horizons are primary ashfall deposits or reworked and redeposited pyroclasts as suggested by Lee et al. (2007). The presence of both forms, primary and reworked tephra, in the same layer could be the result of a winter eruption, when the lake was ice-covered. In this case, reworked tephras from the catchment and primary ashfall deposited on the lake ice cover would be trapped together in different ratios in the lake sediment during the thaw period. Therefore, further detailed studies on the geochemistry of volcanic glasses, including trace and rare earth elements, as well as major element compositions, are needed in order to clarify the eruption ages, source areas, and precise correlations of these tephra deposits.

\section{Conclusions}

The presence of the diamicton at the lowest section of the Limnopolar Lake core demonstrates that we have most probably recovered the complete sedimentary infill of this lake. The chronological model of Limnopolar Lake sediments suggests an earlier deglaciation in Byers Peninsula than that reported in previous studies (Björck et al. 1996, Ingólfsson 2004). Our data from Limnopolar Lake suggest that the central plateau of Byers Peninsula was deglaciated at c. 8300 cal yr BP. An abrupt event, at 5400 cal yr BP, suggests that the geomorphological processes in the Byers Peninsula are highly dynamic. The climatic implications of this type of event should be evaluated in future research, but previous studies suggest that a climate deterioration was the main promotor of these geomorphological processes. About 800 years after lake formation, lake sediments were composed of a millimetric alternation of mosses and terrigenous layers, suggesting that lacustrine dynamics have been similar since formation. The presence of Drepanocladus longifolius moss probably indicates that the lake surface was not completely icecovered for long periods of time. The presence of mosses close to the lowermost lacustrine sediments also suggests that the climatic conditions were mild enough to favour colonization following the deglaciation after the end of the early Holocene climate optimum in the west side of the Antarctic Peninsula (Bentley et al. 2009). Furthermore, the alternation of these mosses and volcaniclastic layers suggests that the climate has periodically fluctuated between relatively warm and cold conditions, or that the spatial distribution of the mosses in the lake has changed through time. According to the chronological model, this periodic alternation has been taking place at decadal time scales. The presence of Drepanocladus longifolius also supports the earlier deglaciation onset described by Hall (2010). Furthermore, this also suggests a close source of moss propagules, which point to possible glacial refuges in the Antarctic Peninsula, 
where many of the coastal ice-free areas at present could have been partially ice-free during glacial maxima (Newman et al. 2009).

Intercalated within these decadal-scale alternations between mosses and volcaniclastic sediments a number of tephra layers are found. Our preliminary results partly agree with the regional tephrachronology stratigraphy already available for the north-west of the Antarctica Peninsula and also identify some previously unreported eruptions. An ongoing study of these tephras using SEM will enable us to differentiate between primary and reworked tephras and further refine the regional tephrachronology.

Further paleolimnological research should be carried out in lakes of the Byers Peninsula, following a deglaciation gradient east-west of Rotch Dome, which will provide a detailed record of glacier evolution in the past (retreats and re-advances) and its relationship with Holocene climate dynamics.

\section{Acknowledgements}

Field work was supported by grants REN2000-0435-ANT from the Science and Technology Ministry (Spain) and POL2006-06635/CGL from the Education and Culture Ministry (Spain) in the framework of the International Polar Year 2007-09 activities. Laboratory analyses were supported by grants CTM2009-07869-E/ANT and CSD2007-00067 from the Science and Innovation Ministry (Spain) and grant PP12020 from KOPRI (Korea Polar Research Institute). Publication expenses have been covered by grant CTM2011-12973-E from the Science and Innovation Ministry (Spain). A. Quesada, A. Justel and C. Rochera, from the Limnopolar Project team, helped with coring in 2003 and S. Fassnacht helped in 2008. UTM (Maritime Technology Unit, CSIC) and the captain and crew of the Spanish Navy ship Las Palmas provided us with the logistical support necessary for the expedition. We are grateful to Dominic Hodgson and Christian Hjort for insightful and constructive reviews of the manuscript.

\section{References}

Anisimov, O.A., Vaughan, D.G., Callaghan, T.V., Furgal, C., Marchant, H., Prowse, T.D., Vilhuálmsson, H. \& Walsh, J.E. 2007. Polar regions (Arctic and Antarctic). In Parry, M.L., Canziani, O.F., Palutikof, J.P., van Der Linden, P.J. \& Hanson, C.E., eds. Climate change 2007: impacts, adaptation and vulnerability. Contribution of Working Group II to the Fourth Assessment Report of the Intergovernmental Panel on Climate Change. Cambridge: Cambridge University Press, 653-685.

Appleby, P.G. \& OldField, F. 1978. The calculation of ${ }^{210} \mathrm{~Pb}$ dates assuming a constant rate of supply of unsupported ${ }^{210} \mathrm{~Pb}$ to the sediment. Catena, 5, 1-8.

Appleby, P.G., Richardson, N. \& Nolan, P.J. 1992. Self-absorption corrections for well-type germanium detectors. Nuclear Instruments and Methods in Physics Research B, 71, 228-233.

Appleby, P.G., Nolan, P.J., Gifford, D.W., Godfrey, M.J., Oldfield, F., Anderson, N.J. \& Battarbee, R.W. $1986 .{ }^{210} \mathrm{~Pb}$ dating by low background gamma counting. Hydrobiologia, 141, 21-27.
Baker, P.E., McReath, I., Harvey, M.R., Rooboi, M.J. \& Davies, T.G. 1975. The geology of the South Shetland Islands: V. Volcanic evolution of Deception Island. British Antarctic Survey Scientific Reports, No. 78, 81 pp. Bentley, M.J., Hodgson, D.A., Smith, J.A., Ó Cofaigh, C., Domack, E.W., Larter, R.D., Roberts, S.J., Brachfeld, S., Leventer, A., HJort, C., Hillenbrand, C.D. \& Evans, J. 2009. Mechanisms of Holocene palaeoenvironmental change in the Antarctic Peninsula region. The Holocene, 19, 51-69.

BJöRCK, S. \& ZALE, R. 1996. Late Holocene tephrochronology and palaeoclimate, based on lake sediment studies. In López-MartínEz, J., THOMson, M.R.A. et al., eds. Geomorphological map of Byers Peninsula, Livingston Island. BAS GEOMAP Series, Sheet 5-A. Cambridge: British Antarctic Survey, 43-48.

Bü̈rck, S., SAndgren, P. \& ZAle, R. 1991a. Late Holocene tephrochronology of the northern Antarctic Peninsula. Quaternary Research, 36, 322-328.

Björck, S., Hjort, C., Ingólfsson, Ó. \& Skog, G. 1991b. Radiocarbon dates from the Antarctic Peninsula - problems and potential. In Lowe, J.J., ed. Radiocarbon dating: recent applications and future potential. Quaternary Proceedings, 1, 55-65.

Björck, S., Håkansson, H., Olsson, S., Barnekow, L. \& Janssens, J. 1993. Palaeoclimatic studies in South Shetlands Islands, Antarctica, based on numerous stratigraphic variables in lake sediments. Journal of Paleolimnology, 8, 233-272.

BJörck, S., Håkansson, H., Zale, R., Karlén, W. \& Jönsson, B.L. 1991c. A late Holocene lake sediment sequence from Livingston Island, South Shetland Islands, with palaeoclimatic implications. Antarctic Science, 3, 61-72.

Björck, S., HJort, C., Ingólfsson, Ó., Zale, R. \& Ising, J. 1996. Holocene deglaciation chronology from lake sediments. In López-Martínez, J., THomson, M.R.A. et al., eds. Geomorphological map of Byers Peninsula, Livingston Island. BAS GEOMAP Series, Sheet 5-A. Cambridge: British Antarctic Survey, 49-51.

Blaauw, M. \& Christen, J.A. 2011. Flexible paleoclimate age-depth models using an autoregressive gamma process. Bayesian Analysis, 6 , 457-474.

Chung, F.H. 1974. Quantitative interpretation of X-ray diffraction patterns of mixtures. Journal of Applied Crystallography, 7, 519-531.

FRETZDORFF, S. \& SMELLIE, J.L. 2002. Electron microprobe characterization of ash horizons in sediments from the central Bransfield basin (Antarctic Peninsula): evidence for at least two volcanic sources. Antarctic Science, 14, 412-421.

Galán, L., Vegas, J. \& García-Cortés, A. 2007. Caracterización de las propiedades físicas en registros lacustres mediante GEOTEK Multisensor Core Logger. Aplicación para el estudio paleoclimático del maar de Fuentillejo. In Lario, J. \& Silva, P.G., eds. Contribuciones al estudio del periodo Cuaternario. Sección de Publicaciones de la Escuela Técnica Superior de Ingenieros Industriales, Universidad Politécnica de Madrid, 187-188.

HaLL, B.L. 2010. Holocene relative sea-level changes and ice fluctuations in the South Shetland Islands. Global and Planetary Change, 74, 15-26.

HJoRt, C., Ingólfsson, Ó. \& BJörCK, S. 1992. The last major deglaciation in the Antarctic Peninsula region: a review of recent Swedish Quaternary research. In Yoshida, Y., Kaminuma, K. \& Shiraishi, K., eds. Recent progress in Antarctic earth science. Tokyo: Terra Scientific Publishing Company, 741-743.

Hodgson, D.A., Doran, P.T., Roberts, D. \& McMinn, A. 2004. Paleolimnological studies from the Antarctic and Subantarctic islands. In Pienitz, R., Douglas, M.S.V. \& Smol, J.P., eds. Long-term environmental change in Arctic and Antarctic lakes. Dordrecht: Springer, 419-474.

Hodgson, D.A., Dyson, C.L., Jones, V.J. \& Smellie, J.L. 1998. Tephra analysis of sediments from Midge Lake (South Shetland Islands) and Sombre Lake (South Orkney Islands), Antarctica. Antarctic Science, 10, 13-20. 
Hodgson, D.A., Noon, P.E., Vyverman, W., Bryant, C.L., Gore, D.B., Appleby, P., Gilmour, M., Verleyen, E., Sabbe, K., Jones, V.J., EllisEvans, J.C. \& Wood, P.B. 2001. Were the Larsemann Hills ice-free through the Last Glacial Maximum? Antarctic Science, 13, 440-454.

InGÓLFSSON, O. 2004. Quaternary glacial and climate history of Antarctica. In Ehlers, J. \& GibBard, P.L., eds. Quaternary glaciations - extent and chronology, Part III. New York: Elsevier, 3-43.

Ingólfsson, O., Huort, C. \& Humlum, O. 2003. Glacial and climate history of the Antarctic Peninsula since the Last Glacial Maximum. Arctic, Antarctic, and Alpine Research, 35, 175-186.

Keller, R.A., Fisk, M.R., White, W.M. \& Birkenmajer, K. 1991. Isotopic and trace element constraints on mixing and melting models of marginal basin volcanism, Bransfield Strait, Antarctica. Earth and Planetary Science Letters, 111, 287-303.

Lee, Y.I., Lim, H.S., Yoon, H.I. \& Tatur, A. 2007. Characteristics of tephra in Holocene lake sediments on King George Island, West Antarctica: implications for deglaciation and paleoenvironment. Quaternary Science Reviews, 26, 3167-3178.

Li, S.P., Ochyra, R., Wu, P.C., Seppelt, R.D., Cai, M.H., Wang, H.Y. \& Li, C.S. 2009. Drepanocladus longifolius (Amblystegiaceae), an addition to the moss flora of King George Island, South Shetland Islands, with a review of Antarctic benthic mosses. Polar Biology, 32, 1415-1425.

López-Martínez, J., Serrano, E. \& Martínez de Pisón, E. 1996. Geomorphological features of the drainage system. In LóPEZ-MARTíneZ J., Thomson M.R.A. et al., eds. Geomorphological map of Byers Peninsula, Livingston Island. BAS GEOMAP Series, Sheet 5-A. Cambridge: British Antarctic Survey, 15-19.

López-Martínez, J., Serrano, E., Schmid, T., Mink, S. \& Linés, C. 2012. Periglacial processes and landforms in the South Shetland Islands (northern Antarctic Peninsula region). Geomorphology, 55, 62-79.

Matthies, D., Mäusbacher, R. \& Storzer, D. 1990. Deception Island tephra: a stratigraphical marker for limnic and marine sediments in Bransfield Strait area, Antarctica. Zentralblatt für Geomorphologie und Paläontologie, 33, 219-234.

Mäusbacher, R., Muller, J., Munnich, M. \& Schmidt, R. 1989. Evolution of postglacial sedimentation in Antarctic lakes (King George Island). Zeitschrift für Geomorphologie, 33, 219-234.

McCormac, F.G., Hogg, A.G., Blackwell, P.G., Buck, C.E., Higham, T.F.G. \& ReIMER, P.J. 2004. SHCal04 Southern Hemisphere calibration 0-11.0 cal Kyr вр. Radiocarbon, 46, 1087-1092.

Newman, L., Convey, P., Gibson, J.A.E. \& Linse, K. 2009. Antarctic paleobiology: glacial refugia and constraints on past ice-sheet reconstructions. PAGES news, 17(1), 22-24.

Oksanen, J., Blanchet, F.G., Kindt, R., Legendre, P., Minchin, P.R., O’Hara, R.B., Simpson, G.L., Solymos, P., Henry, M., Stevens, H. \& WAGNeR, H. 2012. vegan: community ecology package. $\mathrm{R}$ package version 2.0-3. http://CRAN.R-project.org/package $=$ vegan

Pallàs， R., Smellie, J.L., Casas, J.M. \& Calvet, J. 2001. Using tephrochronology to date temperate ice: correlation between ice tephras on Livingston Island and eruptive units on Deception Island volcano (South Shetland Islands, Antarctica). The Holocene, 11, 149-160.
Quayle, W.C., Peck, L.S., Peat, H., Ellis-Evans, J.C. \& Harrigan, P.R. 2002. Extreme responses to climate change in Antarctic lakes. Science, 295, 645-645.

R Development Core Team. 2012. R: a language and environment for statistical computing. Vienna: Wirtschafts University, http://www. R-project.org/

Smellie, J.L. 1990. Graham Land and South Shetland Islands: summary. Antarctic Research Series, 48, 303-312.

Smellie, J.L. 1999. The upper Cenozoic tephra record in the south polar region: a review. Global and Planetary Change, 21, 51-70.

Sterken, M., Roberts, S.J., Hodgson, D.A., Vyverman, W., Balbo, A.L., Sabbe, K., Moreton, S.G. \& Verleyen, E. 2012. Holocene glacial and climate history of Prince Gustav Channel, northeastern Antarctic Peninsula. Quaternary Science Reviews, 31, 93-111.

Sugden, D.E. \& Clapperton, C.M. 1986. Glacial history of the Antarctic Peninsula and South Georgia. South African Journal of Science, 82, 508-509.

Tatur, A., del Valle, R. \& Barczuk, A. 1999. Discussion on the uniform pattern of Holocene tephrochronology in South Shetland Islands, Antarctica. Polish Polar Studies, XXVI Polar Symposium. Lublin: Maria Curie Sklodowska University Press, 303-321.

Toms, P.S., King, M., Zárate, M.A., Kemp, R.A. \& Foit JR, F.F. 2004. Geochemical characterization, correlation, and optical dating of tephra in alluvial sequences of central western Argentina. Quaternary Research, 62, 60-75.

Toro, M., Camacho, A., Rochera, C., Rico, E., Bañón, M., FernándezValiente, E., Marco, E., Justel, A., Avendaño, M.C., Ariosa, Y., Vincent, W.F. \& QuesadA, A. 2007. Limnological characteristics of the freshwater ecosystems of Byers Peninsula, Livingston Island, in maritime Antarctica. Polar Biology, 30, 635-649.

Turner, J., Colwell, S.R., Marshall, G.J., Lachlan-Cope, T.A., Carelton, A.M., Jones, P.D., Lagun, V., Reid, P.A. \& Iagovkina, S. 2005. Antarctic climate change during the last 50 years. International Journal of Climatology, 25, 279-294.

Vaughan, D.G., Marshall, G., Connolley, W.M., Parkinson, C., Mulvaney, R., Hodgson, D.A., King, J.C., Pudsey, C.J., Turner, J. \& WolfF, E. 2003. Recent rapid regional climate warming on the Antarctic Peninsula. Climate Change, 60, 243-274.

Watcham, E.P., Bentley, M.J., Hodgson, D.A., Roberts, S.J., Fretwell, P.T., Lloyd, J.M., Larter, R.D., Whitehouse, P.L., Leng, M.J., Monien, P. \& MoREton, S.G. 2011. A new relative sea level curve for the South Shetland Islands, Antarctica. Quaternary Science Reviews, 30, 3152-3170.

Willmott, V., Domack, E.W., Canals, M. \& Brachfeld, S. 2006. A high resolution relative paleointensity record from the Gerlache-Boyd paleoice stream region, northern Antarctic Peninsula. Quaternary Research, 66, 1-11.

Wolfe, A.P., Miller, G.H., Olsen, C.A., Forman, S.L., Doran, P.T. \& Holmgren, S.U. 2004. Geochronology of high latitude lake sediments. In Pienitz, R., Douglas, M.S.V. \& SMol, J.P., eds. Long-term environmental change in Arctic and Antarctic lakes. Dordrecht: Springer, 19-52. 